\title{
Vegetation history around Yongneup moor at Mt. Daeamsan, Korea
}

\author{
Byeong-O Jang ${ }^{1}$, Sang Joon Kang ${ }^{2}$ and Kee Ryong Choi ${ }^{1, *}$ \\ ${ }^{1}$ Department of Biological Science, University of Ulsan, Ulsan 680-749, Korea \\ ${ }^{2}$ Department of Biology Education, Chungbuk National University, Cheongju 361-763, Korea
}

\begin{abstract}
A pollen analytical study of sediment sequences collected from Yongneup moor (sampling point: $38^{\circ} 12^{\prime} 57.4^{\prime \prime} \mathrm{N}$, $120^{\circ} 7^{\prime} 30.2^{\prime \prime}$ E) was conducted to understand the vegetation history in the mountainous region of the central Korean peninsula. Carbon dating was carried out to measure five successive samples obtained from the bottom at a depth of $180 \mathrm{~cm}$ to the surface. The Yongneup moor sediment revealed four main local pollen zones; that is, four past vegetation phases as follows: Local pollen zone I: Quercus-Pinus zone; estimated age, 5,900-4,800 calibrated years (cal) before present (BP); vegetation type, cool-temperate central/montane deciduous broad-leaved forest. Local pollen zone II: Pinus-Abies-Quercus zone; estimated age, 4,800-3,400 cal BP; vegetation type, cool-temperate northern/alti-montane mixed coniferous and deciduous broad-leaved forest. Local pollen zone III: Quercus-Pinus-Abies zone; estimated age, 3,400-400 cal BP; vegetation type: cool-temperate central/montane deciduous broad-leaved forest. Local pollen zone IV: Pinus-Quercus zone; estimated age, 400-present cal BP; vegetation type, cool-temperate central/montane mixed deciduous broad-leaved and coniferous forest. It was confirmed that subalpine coniferous forests had expanded to the mountainous region of the central Korean peninsula during the period from 4,800-3,400 cal BP and thereafter deciduous forests dominated by Q. mongolica were established. Notably, secondary forests dominated by P. densiflora developed in the lower part of the mountainous region of the central Korean peninsula about $400 \mathrm{cal}$ BP due to human interference.
\end{abstract}

Key words: cool-temperate forest, Holocene, pollen analysis, vegetation history, Yongneup moor

\section{INTRODUCTION}

Environmental change is a continuous process that is well recorded in only a few ecosystems. Among these are high moors (bogs), which are remarkable archives of long-term natural changes, because they document vegetation history within peat that accumulates almost continuously over several millennia (Charman 2002, Robichaud and Bégin 2009). The development of bogs is influenced in a complex combination by autogenic processes (peat build-up) and allogenic forces such as climate, disturbances, and topography (Tolonen 1987, Korhola 1992, Kuhry et al. 1993, Charman 2002).

Yongneup moor is developing at the northwestern slope of Mt. Daeamsan (1,304 m) at the boundary between Inje-gun county and Yanggu-gun county, Gangwon-do province, Korea. Yongneup was first classified as a high moor (German classification) or a raised bog (England classification) by the demilitarized zone (DMZ) survey team in 1967, and, thereafter, much attention has been paid to the Yongneup moor because it is a unique raised bog in Korea (Kang et al. 2010).

Pollen analysis is the principal technique used to document and reconstruct past vegetation and environments of the local region around raised bogs (Birks and Birks 1980). Since Yamazaki (1940) reported the first pol-

\section{Open Access http://dx.doi.org/10.5141/JEFB.2011.028}

This is an Open Access article distributed under the terms of the Creative Commons Attribution Non-Commercial License (http://creativecommons org/licenses/by-nc/3.0/) which permits unrestricted non-commercial use distribution, and reproduction in any medium, provided the original work is properly cited.
Received 03 March 2011, Accepted 04 April 2011

*Corresponding Author

E-mail: pollen@ulsan.ac.kr Tel: +82-52-259-2397 
len analysis of Saeseok Pyeongjeon (a wet grassland) at Mt. Jirisan located in the southern part of Korea, a period followed of over 30 years in which pollen analysis studies and reconstructions of vegetation history were not conducted in Korea. By the end of the 1970s, studies using accurate ${ }^{14} \mathrm{C}$-dating were conducted on sediments in the east-central lowlands and the sub-mountain areas including Lake Youngrangho on the Korean peninsula (Jo 1979, Yasuda et al. 1978, Yoon 1998, Fujiki and Yasuda 2004, Park 2005).

However, studies on changes in past vegetation obtained from mountainous or subalpine wetland sediments were not performed except for those at Yongneup moor, which developed in the mountainous area of the east-central inland of the Korean peninsula. Therefore, it was assumed that Yongneup bog would be a suitable site to reconstruct the development and changes in past local vegetation. Previous pollen analytical studies on this moor (Kang 1980, Chang et al. 1987) were limited in reconstructing past vegetation changes, because their radiocarbon dating results were insufficient and they collected a small number of peat samples.

In the present study, we attempted to reconstruct changes in the local vegetation of the mountainous area of the central Korean peninsula using pollen analysis in parallel with radiocarbon dating of a number of samples collected from the peat sediments of Yongneup moor known as a unique high moor (raised bog) in Korea. The results obtained from this study will provide information for understanding the past local vegetation around Mt. Daeamsan.

\section{MATERIALS AND METHODS}

\section{Study site}

Yongneup moor is a depressive wetland with an area of $7,490 \mathrm{~m}^{2}$ on the northwestern slope of Mt. Daeamsan (Fig. 1). The surrounding area $\left(1.06 \mathrm{~km}^{2}\right)$, including Yongneup, was first designated as an Ecosystem Conservation Area in 1989 but an expanded area of $1.36 \mathrm{~km}^{2}$, including two other nearby wetlands, were considered an Ecosystem Conservation Area in 2010.

Furthermore, the Yongneup moor itself was registered as a Ramsar Convention Wetland on March 28, 1997 for the first time in Korea and Yongneup was designated as a Wetland Conservation Area in 1999. Additionally, nearby mountains such as Mt. Dosolsan (1,478 m), Daewoosan $(1,179 \mathrm{~m})$, Baekseoksan $(1,142 \mathrm{~m})$, and Samyeongsan

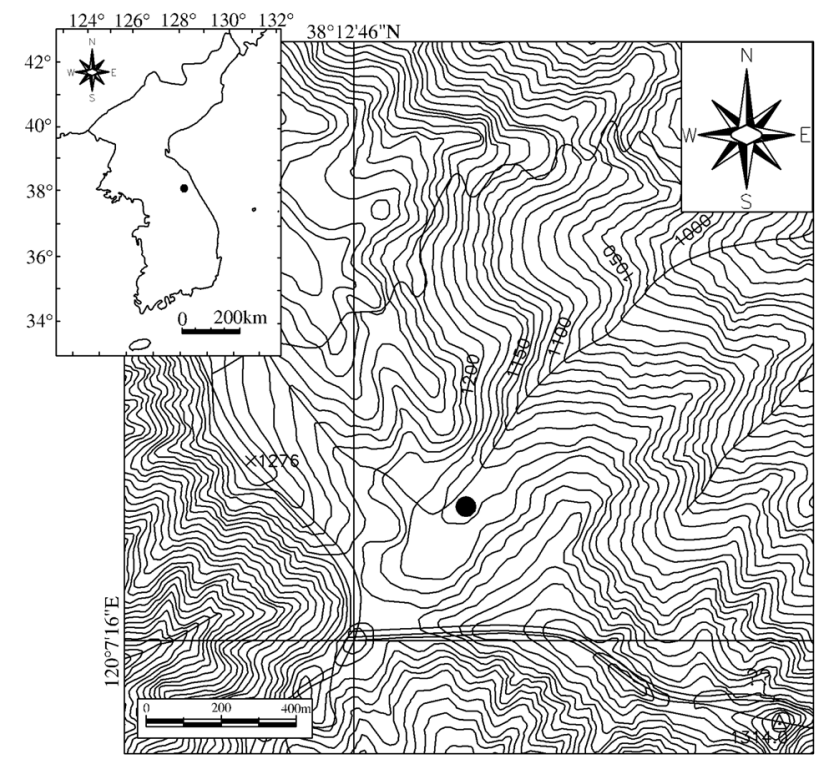

Fig. 1. Map showing the sampling site $(\bullet)$ of the Yongneup moor at Mt. Daeamsan, Gangwon-do province, Korea.

$(1,198 \mathrm{~m})$ including Mt. Daeamsan were designated as Nature Reserves in 1973.

\section{Vegetation around Yongneup moor}

Actual vegetation on the mountains around Yongneup moor is composed of deciduous broad-leaved forest dominated by Quercus mongolica. Besides Q. mongolica, Abies nephrolepis and Pinus koraiensis are mainly scattered on mountains over 1,000 $\mathrm{m}$ and on rocky ridges near the summit of Mt. Daeamsan, respectively.

In contrast, Pinus densiflora is rarely observed on mountains higher than 1,200 m, but appear as mixed forests with $Q$. mongolica with decreases in elevation. At the foot of the mountain, mixed forests of P. densiflora and Quercus variabilis occur. P. densiflora is the dominant tree species in residence areas (Min et al. 2000, Ministry of Environment of Korea 2007).

\section{Climate}

To understand the climatic characteristics around Yongneup moor, we constructed a climate-diagram (Walter et al. 1975) using meteorological information measured at Inje Meteorological Station during the 30 years from 1979-2008 (Fig. 2).

The average temperature was $10.0^{\circ} \mathrm{C}$ and annual precipitation was $1,187.5 \mathrm{~mm}$. The mean temperature in August (warmest month) is $23.2^{\circ} \mathrm{C}$ and that in Janu- 
ary (coldest month) is $-5.1^{\circ} \mathrm{C}$. Approximately $60 \%$ of all precipitation occurs from June to August. A period of greater than $100 \mathrm{~mm}$ of monthly precipitation occurs for 4 months from June to September. Such a precipitation pattern is similar to other regions on the Korean peninsula. In particular, a severe dry month, limiting plant growth, does not occur at Yongneup moor.

\section{Pollen analysis and radiocarbon dating}

A pollen analysis is a tool to reconstruct vegetation history from a particular location over time. Sediment sample cores for the present study were collected using a Hiller type peat-borer at $38^{\circ} 12^{\prime} 57.4^{\prime \prime} \mathrm{N}, 120^{\circ} 7^{\prime} 30.2^{\prime \prime}$ E (Fig. 1). As shown in Fig. 3 and Table 1, five successive samples for ${ }^{14} \mathrm{C}$-dating were obtained from the bottom, at a depth of $180 \mathrm{~cm}$, to the surface and were transported to the AMS facility at Seoul National University. Radiocarbon years were converted to calendar years using the CalPal program available online (Danzeglocke et al. 2008). The 61 sediment samples for pollen analysis were also sub-sampled in parallel with a description of sediment properties using revised soil color charts (Oyama and Takehara 1997).

Standard procedures, including $10 \% \mathrm{KOH}$ treatment, heavy-liquid separation with $\mathrm{ZnCl}_{2}$ (specific gravity 1.681.70), and subsequent acetolysis (Erdtman 1943, 1960, Fægri and Iversen, 1989) were used to extract pollen from the sediment samples. Pollen and spores mounted in glycerin jelly were counted under a light microscope at magnifications of $\times 400-1,000$.

Identification of pollen and spores was aided using previously published studies (Wodehouse 1935, Erdtman 1986, Fægri and Iversen 1989) and by comparing the pollen and spores to reference pollen samples collected and treated at the University of Ulsan. More than 300 pollen grains and spores were counted based on the amount of arboreal pollen (AP) per slide. A pollen diagram was created using relative pollen frequency (RPF) based on the AP.

\section{RESULTS}

Identified pollen and spores were classified into AP (trees) and non-arboreal pollen (NAP, shrubs, herbs, and spores). The scientific names used are the families or genera of the pollen corresponding to the plant.

AP was as follows: Abies, Acer, Betula, Carpinus, Castanea, Celtis, Fraxinus, Juglans, Picea, Pinus, Platycarya,

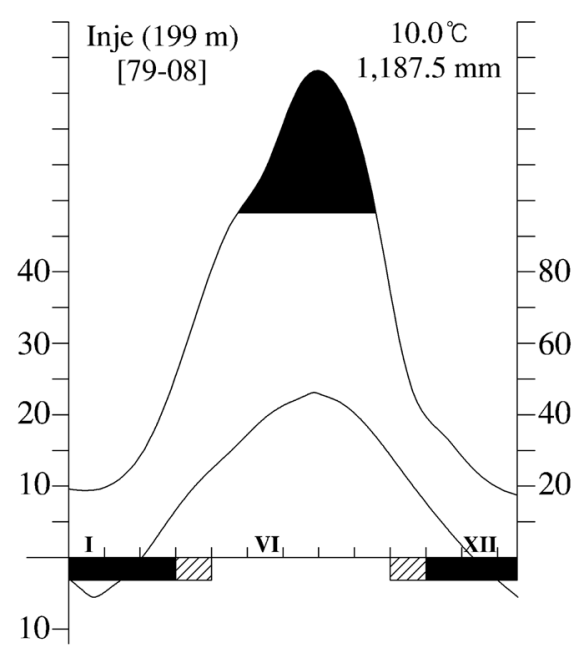

Fig. 2. Climate diagram for Inje-gun county, Gangwon-do province, Korea.

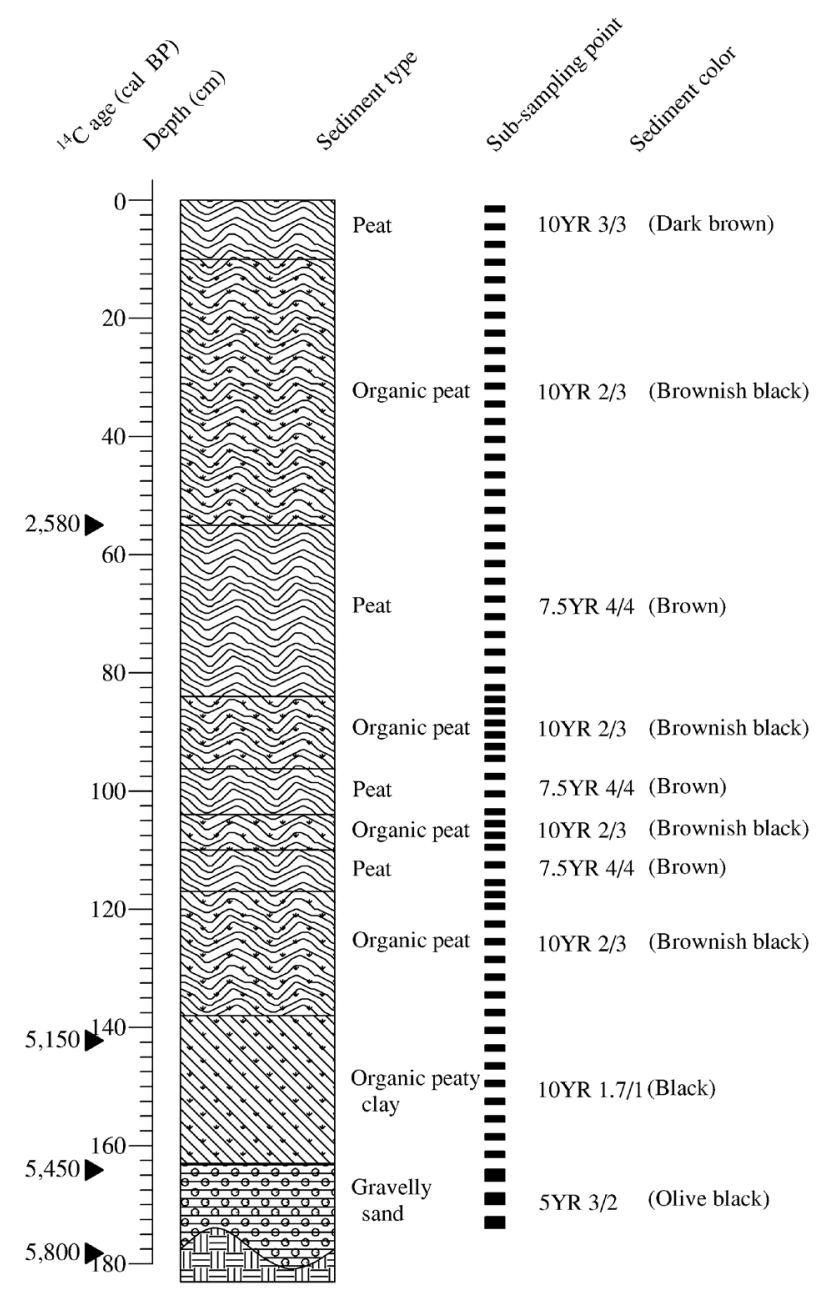

Fig. 3. Vertical facies succession of the sediment core collected from the Yongneup moor at Mt. Daeamsan, Gangwon-do province, Korea. Cal BP, calibrated years before present. 
Pterocarya, Quercus, Tilia, Tsuga, and Ulmus + Zelkova.

NAP was as follows: Alnus, Araliaceae, Celastraceae, Corylus, Lespedeza, Ligustrum, Lonicera, Meliosma, Rhododendron, Rhus, Salix, Staphylea, Symplocos, Weigela, Aconitum, Artemisia, Astilbe, Bistorta, Caryophyllaceae, Chenopodiceae, Clematis + Caltha, Cruciferae, Cucurbitaceae, Cyperaceae, Drosera, Eriocaulon, Geranium, Gramineae, Haloragis, Impatiens, Iris, Juncaceae, Leonurus type, Liliaceae, Lysimachia, Lythrum, Menyanthes, Onagraceae, other Compositae, other Labiatae, other Rosaceae, Parnassia, Patrinia, Persicaria, Plantago, Polygonum, Ranunculus, Sagittaria, Sanguisorba, Scabiosa, Sedum, Thalictrum, Typha, Umbelliferae, Vicia, monolete spores, and trilete spore.

\section{Physical characteristics of sediment}

The vertical facies of the sediment core collected from the Yongneup moor are presented in Fig. 3. Of the entire $180 \mathrm{~cm}$, the upper layer from a depth of $138 \mathrm{~cm}$ to the surface was mainly composed of peat or organic peat.

The layer between 180-163 cm was gravelly sand containing some clay, and the color of these layers was olive black due to the small quantity of organic matter. The layer between 163-138 cm was organic peaty clay containing indistinguishable organic remains and distinguishable plant debris with the naked eye. The color of these layers was black. The layer between 138-10 cm alternated repeatedly with brownish and humified peat, indicating the relative difference in the humification of peat. The layer from $10 \mathrm{~cm}$ to the surface was composed of dark brown peat, suggesting that this upper layer was affected and disturbed by the peat sampling procedure because of its high water content.

From the physical features described above, soil components from the vicinity of the slope at Yongneup moor did not flow from the $138 \mathrm{~cm}$ depth layer to the surface. Accordingly, it was inferred that the peat sediment of

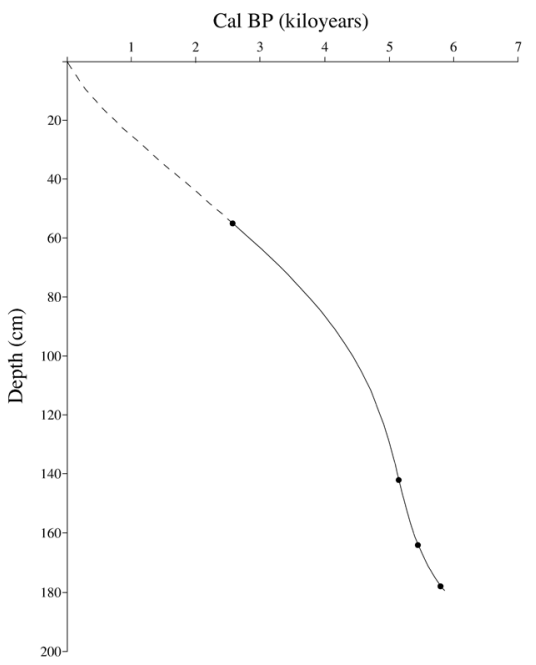

Fig. 4. Age-depth curve based on the accelerator mass spectrometry radiocarbon dating results obtained from sediment samples of Yongneup moor at Mt. Daeamsan, Gangwon-do province, Korea. Cal BP, calibrated years before present.

these upper layers was only composed of autochthonous plant remains, including air-born pollen and spores, as well as allochthonous dust and aerial deposition.

\section{${ }^{14} \mathrm{C}$-dating}

It was confirmed by ${ }^{14} \mathrm{C}$-dating that the Yongneup moor was initiated by the formation of a concave wetland approximately 5,900 calibrated years (cal) before present (BP) (Table 1). An age-depth curve was plotted in Fig. 4 to estimate the sediment ages using the ${ }^{14} \mathrm{C}$-dating results.

\section{Pollen analysis}

To facilitate discussion of the pollen record, the pollen diagram was subdivided into four local pollen zones (LPZ) based on the percentage of the principal pollen and spores (Fig. 5)

Table 1. AMS radiocarbon ages of sediment samples obtained from the Yongneup moor on Mt. Daeamsan, Gangwon-do province, Korea

\begin{tabular}{lccccc}
\hline Sample No. & Depth level $(\mathbf{c m})$ & Dated material & Lab. No. & Age in ${ }^{14}$ C BP & Age in cal BC/AD \\
\hline Yongneup-site 6-1 & $54-56$ & Sediment & SNU08-722 & $2,510 \pm 50$ & $630 \mathrm{BC}$ \\
Yongneup-site 6-2 & $88-90$ & Sediment & SNU08-723 & $1,800 \pm 50$ & $220 \mathrm{AD}$ \\
Yongneup-site 6-3 & $141-143$ & Sediment & SNU08-724 & $4,480 \pm 50$ & $3,200 \mathrm{BC}$ \\
Yongneup-site 6-4 & $163-165$ & Sediment & SNU08-725 & $4,740 \pm 50$ & $3,500 \mathrm{BC}$ \\
Yongneup-site 6-5 & $177-179$ & Sediment & SNU08-726 & $5,060 \pm 50$ & $3,850 \mathrm{BC}$ \\
\hline
\end{tabular}

AMS, accelerator mass spectrometry; BP before present; Cal, calibrated years; BC, before Christ; AD, Anno Domini.

*Eliminated to construct the age-depth curve.

${ }^{\dagger}$ SNU 08: code number for the AMS Center of Seoul National University. 


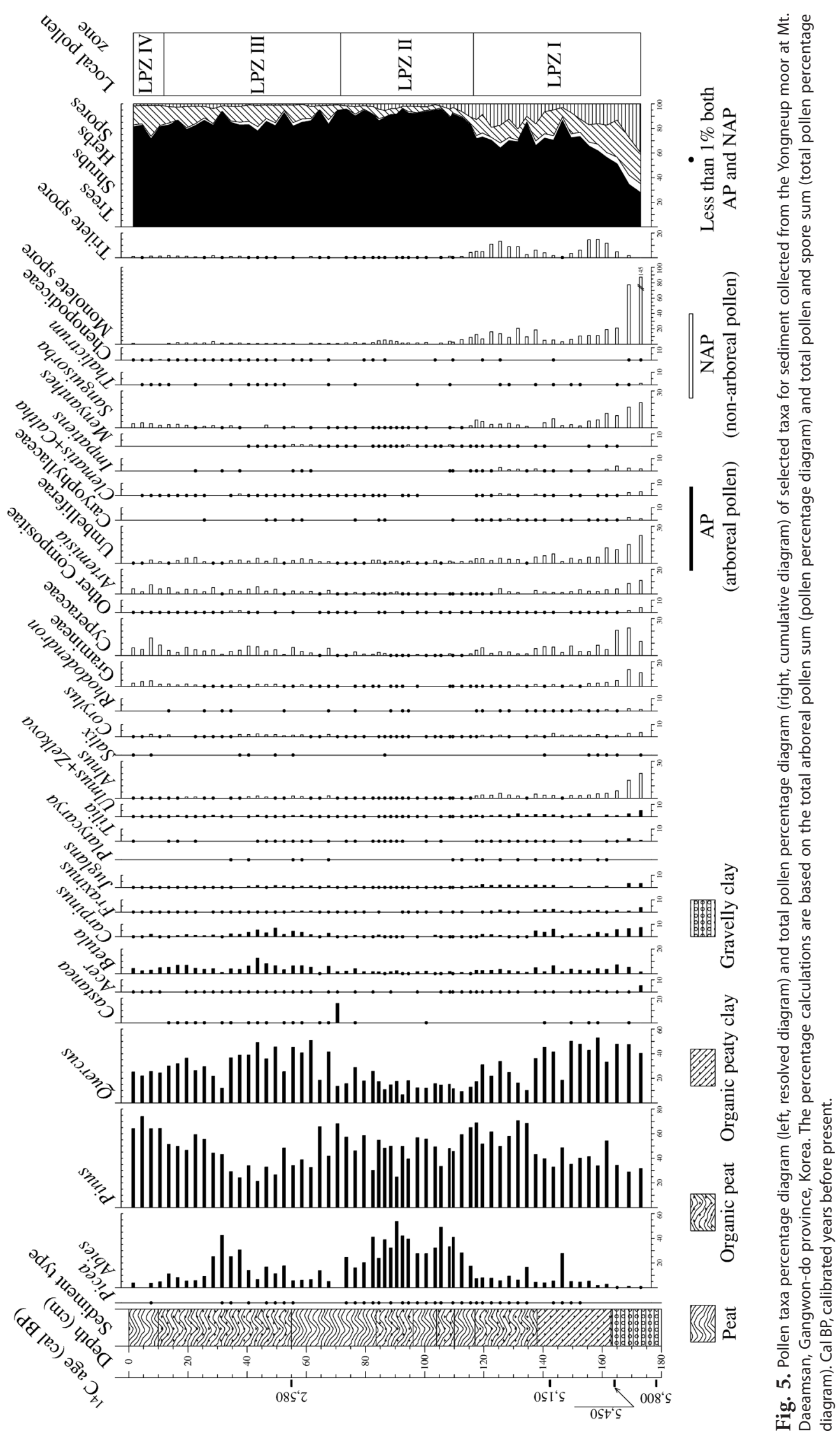




\section{LPZ-I (Quercus-Pinus zone)}

The pollen spectra during the period 5,900-4,800 cal BP (lower sediment) were characterized by high percentages of Quercus (30-50\%) and Pinus (29-70\%), whereas the frequency of Abies was $<10 \%$ throughout the LPZ-I zone. Among tree pollen taxa, Betula and Carpinus revealed relatively high percentages.

Pollen of the shrubby Alnus, an indicator of the local environment, was relatively abundant. This taxon appeared in approximately $20 \%$ of the bottom layers and then decreased gradually toward the upper layer of LPZ I. Herbaceous pollen taxa such as Cyperaceae, Artemisia, Umbelliferae, and Sanguisorba predominated in this pollen zone compared to other herbaceous taxa. In contrast, the pollen assemblages of Abies and Pinus began to increase and that of Quercus began to decrease in this pollen zone.

\section{LPZ-II (Pinus-Abies-Quercus zone)}

The LPZ-II zone was estimated to be 4,800-3,400 cal BP and was characterized by rapid increases in Abies and Pinus and by abrupt decreases in Quercus, including other deciduous broad-leaved taxa. The percentage $A b$ ies pollen generally exceeded $15 \%$ throughout this zone and occasionally reached $49 \%$. Pinus pollen occupied $24-65 \%$.

Compared with the pollen frequency in the LPZ-I zone, Quercus in the LPZ-II zone showed lower percentages of $10-17 \%$. Additionally, deciduous broad-leaved tree pollen taxa composed of a tall-tree layer comprised < $1 \%$. Herbaceous pollen and spores occurred in relatively low percentages compared with the LPZ-I zone. Quercus began to increase again and Abies and Pinus began to decrease in this pollen zone.

\section{LPZ-III (Quercus-Pinus-Abies zone)}

The LPZ-III zone was estimated to be $3,400-390$ cal BP. The vegetation information on the LPZ-III zone was obtained from the $72-12 \mathrm{~cm}$ depth sediment layer. The LPZIII zone was characterized by an increase in Quercus and a decrease in Pinus and Abies. Quercus pollen exceeded $50 \%$, whereas that of Pinus occurred at $68 \%$ in the lower layer, but decreased to $21 \%$ in the upper layer of the LPZIII zone. Abies pollen occurred at an overall frequency of $10-15 \%$. Among the other AP pollens, Betula and Carpinus occurred in relatively high percentages. Herbaceous pollen and spores were also slightly higher than those in the LPZ-II zone.

\section{LPZ-IV (Pinus-Quercus zone)}

The LPZ-IV zone was estimated to be 390-present cal BP was the uppermost zone including sediment at depths of $12-0 \mathrm{~cm}$. This zone was characterized by rapid increases in Pinus and by abrupt decreases in Abies.

Abies pollen, which occurred at relatively high percentages in the LPZ-III zone decreased to $<10 \%$ and, thereafter, this taxon showed a continually decreasing trend in this zone. In contrast, Pinus pollen showed a rapidly increasing trend to $74 \%$. The Quercus pollen assemblage was consistently maintained at a frequency of $22-25 \%$, although the frequency was lower than that in the LPZ-III zone.

\section{DISCUSSION}

From the ${ }^{14} \mathrm{C}$-dating results, the bottom sediments began to form in the Yongneup moor approximately 5,900 cal BP. The successive pollen spectra in Yongneup moor sediment provided information for reconstructing the changes in past vegetation on local and regional scales in the mid-late Holocene. The Korean peninsula vegetation types for reconstructing past vegetation were based on Yim and Kira (1975), Yim (1977a, 1977b), and Kim (1992). Decisions about past vegetation based on the pollen assemblages were based on Choi $(1997,1998)$ and Song (2002). Chang et al. (1987) has conducted analytical pollen studies on this moor, but they did not perform radiocarbon dating. Furthermore, their RPF calculation method differed from that used in the present study. Therefore, we compared our relative similarities with those of the main AP RPFs, as a direct comparison to their results was difficult.

According to the pollen assemblage spectra in the LPZ-I zone, which occurred 5,900-4,800 cal BP, it was inferred that past vegetation along the foot to the slope of Mt. Daeamsan was composed predominantly of $Q$. mongolica mixed forest with Carpinus, Betula, and Fraxinus. In other words, cool temperate central/montane deciduous broad-leaved forest probably developed in this area. However, this suggested that the cool temperate northern/alti-montane mixed coniferous and deciduous broad-leaved forest developed at the summit and the surrounding area of Mt. Daeamsan. The past forest on the top of the mountain was dominated by Q. mongolica, P. koraiensis, Abies holophylla, and A. nephrolepis.

The Alnus pollen assemblage and herbaceous taxa in the LPZ-I zone had noticeably higher percentages in contrast to the upper layers, indicating that a depressive bottom during the initial period of Yongneup develop- 
ment maintained poor drainage conditions originating from the formation of wet soil including fine sand, silt, and clay. Alnus japonica is an indicator shrub that grows on wet soil such as moors, fens, and swamps. The abundance of Alnus pollen in the LPZ-I zone indicated that A. japonica inhabited Yongneup bog or its surrounding mountain foot. In other words, other AP trees did not develop in the moor and/or nearby mountain areas due to the wet soil conditions. In contrast, herbaceous taxa such as Cyperaceae, Artemisia, Umbelliferae, and Sanguisorba occurred at relatively higher densities.

Considering the variations in fossil pollen and spores during LPZ-II $(4,800-3,400$ cal BP), it is estimated that subalpine coniferous forest developed at the outskirts of Yongneup moor and along the ridge to the summit of Mt. Daeamsan. This indicates that the subalpine coniferous forest, composed of A. holophylla, A. nephrolepis, and $P$. koraiensis, spread quickly along the foot up to the summit of Mt. Daeamsan and occupied the surrounding area during this period.

The high percentages of subalpine pollen taxa in the LPZ-II occurred because the subalpine coniferous forest, such as A. holophylla, A. nephrolepis, and Picea jezoensis descended vertically and expanded at lower elevations. Additionally, it can be inferred that the cool temperate northern/alti-montane mixed coniferous and deciduous broad-leaved forest, composed of Q. mongolica and P. koraiensis, covered most of the mountainous parts below the Mt. Daeamsan piedmont. Judging from the fluctuations in Pinus and Quercus, this pollen zone was comparable to pollen zone I of Chang et al. (1987); however, $A b$ ies did not appear clearly as in our study.

During the period from 3,400-390 cal BP (LPZ-III), $A b$ ies and Pinus taxa, which were distributed during the previous LPZ-II period, retreated to the summit or areas further north than Mt. Daeamsan. Therefore, it is inferred that the retreated Abies and Pinus taxa were replaced by Quercus and other deciduous broad-leaved species. In other words, Quercus, which dominated below the mountainside in the previous period, developed above the mountainside or near the summit areas, indicating that cool temperate northern/alti-montane mixed coniferous and deciduous broad-leaved forest covered most of the summit area, whereas cool temperate central/montane deciduous broad-leaved forest covered most of the lower regions. Judging from the fluctuations in Pinus and Quercus, this pollen zone was comparable to pollen zone II of Chang et al. (1987).

The reconstructed vegetation types of this period nearly coincided with those of LPZ-I. However, the per- centages of Abies and Pinus were higher than those of LPZ-I until 1,300 cal BP. These results reflect that the frequency of evergreen subalpine coniferous species, such as A. holophylla, A. nephrolepis, and P. koraiensis, were relatively higher than that of the Quercus-Pinus zone (LPZ-I), which was the bottom sediment. Accordingly, it is inferred that the subalpine coniferous forest ascertained in the previous Pinus-Abies-Quercus zone (LPZ-II) also developed at elevations close to the Mt. Daeamsan summit during the lower to middle parts of LPZ-III.

In LPZ IV (390-present cal BP), the most conspicuous pollen frequency feature was a sharp increase in Pinus and a distinct decrease in Abies. While Quercus was less frequent than the previous period, Quercus pollen was maintained continuously within a range of $22-25 \%$. Such results indicate that coniferous Abies taxa, such as A. holophylla and A. nephrolepis, occurred individually below the middle region and at the community level above Mt. Daeamsan during the previous LPZ-III pollen zone and were rapidly replaced by Pinus (P. densiflora) during the LPZ-IV period This pollen zone was comparable to pollen zone III of Chang et al. (1987).

Based on the pollen composition, the vegetation type surrounding Mt. Daeamsan during LPZ IV was probably cool temperate central/montane mixed deciduous broad-leaved and coniferous forest. The abrupt increase in Pinus pollen in this pollen zone may be pollen dispersed from secondary $P$. densiflora forests formed by humans, who were establishing in the lower regions around Mt. Daeamsan.

\section{CONCLUSION}

A pollen analysis and radiocarbon dating of sediment peat collected from Yongneup moor were conducted to reconstruct past vegetation in the mountainous region of the central Korean peninsula during the Holocene. The 61 pollen analysis samples and the five ${ }^{14} \mathrm{C}$-dating samples were obtained from depths of $180 \mathrm{~cm}$ to the surface. Of the samples collected, the sediments from depths of $130 \mathrm{~cm}$ to the surface were sequential peat.

The year of the bottom sediment was approximately 5,900 cal BP. Four LPZs were identified from the pollen analysis results at Yongneup moor. The past vegetation inferred from the pollen record included: (1) cool temperate central/montane deciduous broad-leaved forest (LPZ-I) during the period from 5,900-4,800 cal BP, (2) cool temperate northern/alti-montane mixed coniferous and deciduous broad-leaved forest (LPZ-II) during the period 
from 4,800-3,400 cal BP, (3) cool temperate central/montane deciduous broad-leaved forest (LPZ-III) during the period of 3,400-390 cal BP and (4) cool temperate cen$\mathrm{tral} /$ montane mixed deciduous broad-leaved and coniferous forest (LPZ-IV) during the period from 390-present cal BP. These pollen zones represent the vegetation dynamics at the different levels and reveal several original features of the areas around Yongneup bog and Mt. Daeamsan since the Holocene.

Although the pollen analysis technique is useful to reconstruct past vegetation, it should be applied in parallel with ${ }^{14} \mathrm{C}$-dated sequences of other subalpine wetlands such as bogs and fens to elucidate past vegetation on the Korean peninsula. Additionally, insufficient data are available, except for Yongneup bog, so further efforts should be made to conduct additional palynological analyses.

\section{LITERATURE CITED}

Birks HJB, Birks HH. 1980. Quaternary Palaeoecology. Edward Arnold, London.

Chang NK, Kim YP, O IH, Son YH. 1987. Past vegetation of moor in Mt. Daeam in terms of the pollen analysis. Korean J Ecol 10: 195-204. (in Korean)

Charman D. 2002. Peatlands and Environmental Change. John Wiley \& Sons, Chichester.

Choi KR. 1997. The vegetation history of the Korean peninsula during the post glacial. Nature Conserv 100: 28-33. (in Korean)

Choi KR. 1998. The post-glacial vegetation history of the lowland in Korean peninsula. Korean J Ecol 21: 169-174.

Danzeglocke U, Jöris O, Weninger B. 2008. CalPal-2007 online. http://www.calpal.de. Accessed 18 December 2010.

Erdtman G. 1943. An Introduction to Pollen Analysis. The Ronald Press Co., New York, pp 27-31.

Erdtman G. 1960. The acetolysis method. Svensk Bot Tidskr 54: 561-564.

Erdtman G. 1986. Pollen Morphology and Plant Taxonomy: Angiosperms. An Introduction to Palynology. E. J. Brill, Leiden.

Fægri K, Iversen J. 1989. Textbook of Pollen Analysis. $4^{\text {th }}$ ed. Blackwell, Oxford.

Fujiki T, Yasuda Y. 2004. Vegetation history during the Holocene from Lake Hyangho, northeastern Korea. Quat Int 123-125: 63-69.

Jo WR. 1979. Palynological studies on postglacial age in eastern coastal region, Korea peninsula. Ann Tohoku Geogr
Assoc 31: 23-35. (in Japanese)

Kang SJ. 1980. A preliminary pollen analytical study of the high moor in the Dae-am Mountain. Theses Collect Chunbuk Natl Univ 19: 253-260.

Kang SJ, Cho KS, Choi KR. 2010. Museum of Alive Nature History Yongnup (High Moor) of Mt. Daeam san in Korea. University of Ulsan Press, Ulsan, pp 23-50. (in Korean)

Kim JW. 1992. Vegetation of northeast Asia. On the syntaxonomy and syngeography of the oak and beech forest. PhD Dissertation. University of Vienna, Vienna, Austria.

Korhola A. 1992. Mire induction, ecosystem dynamics and lateral extension on raised bogs in the southern coastal area of Finland. Fennia 170: 25-94.

Kuhry P, Nicholson BJ, Gignac LD, Vitt DH, Bayley SE. 1993. Development of Sphagnum-dominated peatlands in boreal continental Canada. Can J Bot 71: 10-22.

Min WK, Chang CS, Jeon JI, Kim H, Choi DY, Jung SS. 2000. Flora of Mt. Dae-am-san. Bull Seoul Natl Univ Arboretum 20: 38-82. (in Korean)

Ministry of Environment of Korea. 2007. Natural Ecosystem Map of Seohwa, Imdang. Ministry of Environment, Gwacheon. (in Korean)

Oyama M, Takehara H. 1997. Revised Standard Soil Color Charts. Research Council for Agriculture, Forestry, and Fisheries, Ministry of Agriculture and Forestry in Japan, Tokyo.

Park JH. 2005. Palynological study of bottomland deposits in Sacheoncheon, Gangneung City, Korea. J Korean Geomorphol Assoc 12: 69-77. (in Korean)

Robichaud A, Bégin Y. 2009. Development of a raised bog over 9000 years in Atlantic Canada. Mires Peat 5: 1-19.

Song YJ. 2002. A palynological study of the vegetation history of the southern lowland in the Korean peninsula. PhD Dissertation. University of Ulsan, Ulsan, Korea. (in Korean)

Tolonen K. 1987. Natural history of raised bogs and forest vegetation in the Lammi area, southern Finland studied by stratigraphical methods. Ann Acad Sci Fenn Ser A III 144: 1-46.

Walter H, Harnickel E, Mueller-Dombois D. 1975. ClimateDiagram Maps of the Individual Continents and the Ecological Climatic Regions of the Earth. Springer-Verlag, Berlin, pp 36.

Wodehouse RP. 1935. Pollen Grains: Their Structure, Identification and Significance in Science and Medicine. McGraw Hill Book Co., New York, NY.

Yamazaki T. 1940. Beitrage zur verwandlung der Baunarten im sudlichen Teile von Korea durch die Pollenanalyse. Jpn For Soc 22: 17-29. (in Japanese)

Yasuda Y, Tsukada M, Kim JM, Lee ST, Yim YJ. 1978. The En- 
vironment Changes and the Agriculture Origin in Korea (Preliminary). Japanese Ministry of Education Overseas Research Reports, Tokyo, pp 1-19. (in Japanese)

Yim YJ. 1977a. Distribution of forest vegetation and climate in the Korean peninsula. III. Distribution of tree species along the thermal gradient. Jpn J Ecol 27: 177-189.

Yim YJ. 1977b. Distribution of forest vegetation and climate in the Korean peninsula. IV. Zonal distribution of forest vegetation in relation to thermal climate. Jpn J Ecol 27:
269-278.

Yim YJ, Kira T. 1975. Distribution of forest vegetation and climate in the Korean peninsula. I . Distribution of some indicies of thermal climate. Jpn J Ecol 25: 77-88.

Yoon SO. 1998. The environmental change and geomorphic development of Unsan alluvial plain in Kangreung City during the late Holocene. J Korean Geogr Soc 33: 127142. (in Korean) 